\title{
Kujutelmad üleloomulikest olenditest Virumaa rahvausus ${ }^{1}$
}

\begin{abstract}
Mall Hiiemäe
Teesid: Virumaa rahvausundilises pärimuses on ristiusueelsed animistlikud kujutelmad vaimudest ja haldjatest ning animistlik elava looduse usk mõneski valdkonnas enam säilitanud vanu läänemeresoomelisi ning Põhja-Euraasia metsavööndi uskumusi kui mujal Eestis. See tuleb ilmsiks nt seoses metsa-, vee- ja majavaimukujutelmaga. Germaani ainest on traditsioonis aastasadadega välja kujunenud sisumotiivide näol rohkem üle võetud seoses demoniseerunud vaimolenditega, nt koerakoonlane, kodukäija, libahunt. Eesti folkloorikogude usundipilti iseloomustades kirjutab professor Ülo Valk (2008: 381): "Mida rohkem elav rahvausk hääbub, seda vaesemaks jääb algselt kirev üleloomulike olendite maailm, sest selle asukaid ei osata enam nimetada. Kõige elujõulisemad on ebamäärased kummitused ja lausa universaalne kurat, kes tõrjub kõrvale loodus- ja majahaldjad ning esineb üha enam talle algselt võõrastes rollides.” Kuigi rahvausundilise maailmapildi taandumine ning kristluse mõjustused on kaasa toonud muutusi ja hägustumist, tuleb arvesse võtta, et rahvausundilised kujutelmad ongi loomuldasa ebaühtlased.

Alljärgnev ülevaade kajastab suhteliselt hilist, alates 19. sajandi lõpukümnenditest talletatud suulist rahvapärimust. Täiendav sihipärane andmete kogumine vaimolendite kohta eesti mütoloogias sai teoks 20. sajandi 30. aastatel. Virumaal (Jõhvi, Lüganuse, Viru-Nigula, Väike-Maarja khk) tegeles sellega kõige põhjalikumalt Rudolf Põldmäe. Iseloomustan Virumaa usundilistes muistendites kajastuvaid kujutelmi üleloomulikest vaimolenditest, toon esile nende ühis- ja erijooni ning mõjustatust kultuurikontaktidest (vt ka Hiiemäe 2015).
\end{abstract}

Märksõnad: demoniseerumine, ended, esinemiskuju, irdhing, kultuurikontaktid, mütoloogia

\section{Metshaldjas}

Metshaldjas (aldijas, aljas, allias, algjas) on Virumaa rahvapärimuses võrreldes muude Eestimaa piirkondadega hästi tuntud üleloomulik vaimolend (u 1/4 kirjapanekutest). Välimuselt on ta inimese sarnane, mingi looma kujul näitab end harva. Kirjeldustes on eristatud välimuse erijooni: mees, naine, 
neiu, saksa preili, poisike, suur vanamees, punase-valgekirju lehm jne. Esile on toodud rõivastuse detaile ja värvi, otsekui tõestamiseks, et olendit ikka nähti: preili seisab, sinine jakk, taevakarva seelik, kollased sukad ja kingad (Lüganuse, 1930); tuli üks mees karjamaa äärt mööda ja läks minust mööda, punased sääred, kas paljad või sukkadega, ei tea mina, mustad põlvist saadik püksid ja all kamson seljas (Haljala, 1898). Kohtumisel inimesega on iseloomulik, et haldjas äkki põgeneb või haihtub, või nähakse heinasaadu liikumas.

Üldjoontes kujutab Virumaa rahvapärimus metshaldjat pigem neutraalse kui vaenulikuna.

Aldijad pidid metsas ja meres olema. Tooma eit käis marjas, tema läks üksi. Eksis metsas välja. Sai ühe suure sihi pääle, temale tuld poisike vasta, allis riides. Tema oli irmu täis, kartas juba, ôhta oli. Öeld poisikesele: "Kulla laps, juhata mind kodo poole!" Tema näitand käega ja kadund. Tema akand sinnapoole tulema, kuhu ta näitas ja jõudiski kodo. Tema ütles: "Sina armas aeg, see õli aldijas, miks ta välla kadus. Just selgesti laps õli, aga enam ei rääkind ühte. Eks niiskene õle aldijas, metsaldijas.” (ERA II 38, 699/700 (13) < Vaivara khk ja v < Jõhvi khk - R. Põldmäe (1931).)

Haldjapärimuse kõige populaarsem motiiv on haldja jälgedele sattumisel eksimine. Sihipärast looduses viibiva inimese eksitamist, nagu seda teeb kagueesti essütaja, tuleb Virumaa traditsioonis siiski vähem ette. Lapsi on küll hoiatatud metsa minemast: haldjas hõikab vastu, meelitab metsa ja eksitab ära. Ka metsas magajat tuleb haldjas oma rajalt ära ajama ega lase uinuda. Nimetatud on paiku, kus võimalus haldjat kohata on suurem, nt Rägavere väljal Mullikmäel, Haljalast tulles Liiguste küla väljal ning Sausti küla väljal, Kadrina kihelkonna Hõbeda kuusiku Vatku poolses nurgas, Emumäel, Tudu hiies jm. Metsas eksimise põhjuseks on peetud nimelt haldja jälgedele sattumist. Uskumusi aitasid edasi püsida metsas eksimise juhtumid ja mälestusjutud nendest.

Me käisime kaks pühapäeva metsas, ühekõrra tuli metsaldijas sinna, olime ta jälgide pääl. Õhta tuli kätte, aga ta jälgide päält ei pääse kuskile. Metsküla all metsas see õli. Ei kuule koera äält, olime selle päeva aldija jälgide pääl. Päiv akkas looja menema, koer akkas aukuma, olime küla all. Tulime mõisa, metsavaht ütles: "Mina olen mitu kõrda ta jälgide pääl olnd.” (ERA II 37, 541/2 (5) < Jõhvi khk, Mäetaguse v - R. Põldmäe (1931).)

Üleloomuliku vaimolendi väe mõjul kaotab inimene suunataju: ei tunne tuttavat paika ära, jõuab korduvalt tagasi samasse paika. Olukorrast pääsemiseks, õige 
orientatsiooni saavutamiseks tuleb lummus neutraliseerida. See saavutatakse äraspidiste toimingutega, nagu rõivaeseme - sukkade, kuue, mütsi - teistpidi pööramine, tagurpidi meieisapalve lugemine kolmel korral järjest, kannapealt ümberpööramine vastassuunda minekuks.

Mõnikord on eksimise põhjustajaks peetud surnuvaime, nt muistse sõja aegses kalmulepikus. Demoniseerunud vaimolendi asemel võib aga eksitajaks olla ka vanakuri ise, kelle nimetamist jutustaja targu väldib.

Üle vana ilusa ${ }^{2}$ jälgede peab minema, siis peab eksima. Siis kui oled eksik, siis astu kolm sammu tagurperi tagasi, siis klaarib ära jälle. Mina olin korra eksik. Läksin üle lageda soo Jõhvis, võtsin pohlasi. Aga keerasin ümber, sain sinna tagasi, kus enne olin. Läksin uuesti, jälle sain samasse kohta. Kolm korda sain, siis nägin sõitu, selle järele sain raudtee peale. Mis see eksitas minu - võib-olla vana ilus oli ehk sealt läbi läind. (ERA II 28, 446/7 (6) < Viru-Nigula khk, Kalvi v - R. Põldmäe (1930).)

\section{Veehaldjas, näkk}

Kui veehaldja nimetusena on üldtuntuks saanud laen rootsi keelest näck (vrd ka saksa k Nix) ja rahvausundilises pärimuses võib kohata tugevaid germaani kultuuri mõjustusi, on Virumaal ühtlasi säilinud vana soomeugrilist ettekujutust. Seda vahendab teistsugune nimevalik: veevaim, vetevaim, järvevaim, veehaldjas, vetehaldjas, jõehaldjas, merehaldjas, kaldahaldjas. Uskumuste vanemas kihistuses peitub kujutlus vete haldajast - valitsejast, peremehest, kalade patroonist.

Veekeskkond on seotud teispoolsuse mõistega, ühtaegu aga olmetegevusega (kalapüük, veeteed liikluseks, suplusvõimalused jne). Virumaad piirab kolmest küljest vesi, rohkesti on siseveekogusid - järvi ja jõgesid, nii on ka veekogudel olnud virumaalase elus küllaltki oluline koht.

Kaugete aegade jäänukina rahvasuus 20. sajandisse püsinud muistendites ärarännanud järvedest võib kohata mööndust, et asukoha muutjaks olid vetevaimud. Tudu järve viisid vetevaimud Muraka rabasse, Küti vallas Kehala küla all asunud järve vetevaim viis Mustjärve ära Kuresoosse, sest järves pesti pesu; mõnedki järved ja jõed on asukohta muutnud vee- ja mäevaimu tüli tõttu, nt lahkus jõevaim Ebavere mäe tagant ning seetõttu kuivas ka Pandiverest Avispea ning Väike-Maarja kaudu Ebaverest läbi voolanud veerikas jõgi. Kuid rahvajutus võivad vetevaimud ka hästi läbi saada ja üksteisele terviseid saata. 
Järve aldias, tiigialdias, jõe aldias on selle koha peremees, kes tema õiguse rikkujaid uputamisega trahvib. Isekeskis on keik vesialdiad ühenduses ja käivad läbi, saadavad terviksid. Kosta ja Maheda järves on neil sammeldand seljaga avi kuju, Kahala järves must ärg, Käsmus ema tütrega, Iidjärves hall siig ehk liivalõhe, Arujärves olnud halli jalgadega poiss, kes järve Iidjärve veend. (ERA II 198, 242 (13/4) < Haljala khk - H. Länts (1938).)

Hiidhaugist vetevalitseja asupaigaks teatakse olevat Uljaste järve. Sabata, roheka sammaldunud seljaga vm eritunnustega hiidkala on muistse kalastajakultuuri esindaja - kalajumaluse kehastus või siis tema kariloom. VäikeMaarja kihelkonnast pärit kirjapanekus nõuab veteolend kalamehelt öösel oma “tömpsaba-orikat” tagasi ja see viibki püütud kala tükid järve.

Välimuselt on usundi vanema kihistuse veteolend märksa varieeruvam kui näkk. Antropomorfne vetehaldjas võib olla inimkeeli kõnelev hall vanamees, nooruk, poisike, naine, tüdruk või väike laps. Mereranniku äärsetes külades on haldja nimetust kasutatud rohkem kui sisemaal, tähendus on sama: Näkk on meres, merealdijas (Viru-Nigula, Lahe k); Meres on aldijad, näkk on tema nimi (Lüganuse, Kestla-Ahu k); Merealdijas ehk näkk, see on üks vist (Jõhvi, Toila-Männiku k). Naisterahva välimus on stereotüüpne: tal on pikad juuksed, mida ta kammib või peseb. Kala saba, noorust ja ilu on mainitud enam näki kui veehaldja nimetusega seoses. Teriomorfne vetevaim võib olla fantaasiaolend:

Võsbergi Liine nähänd: seisand joe tokkede pääl karvane loom, hall, inimese pea otsas, saba taga, kapjad all. Tema läend ligemale, kadund ära. See pidi jõealdjas olema. (ERA II 28, 665 (24) < Viru-Nigula khk, Kunda-Malla v - R. Põldmäe (1930).)

Näkikujutelmal on aidanud kauemini traditsioonis püsida hoiatusjutud laste hirmutamiseks. Tüüpiline on lokaliseering: nimetatakse paiku - jõgede hauakohti, järvede allikakohti, kivirahne meres, kus näkil meeldib istuda. Üsna üheilmeline on muistenditüüp hobusena (ka varsa või palgina) ilmuvast näkist, kes lapsi selga istuma meelitab. Olukorra päästab näki nimetamine, mille peale see äkki kaob:

Palava ilmaga mänginud lapsed Tõldjõe kaldal. Nende juure tulnud ilus must täkk. Lapsed istunud hobuse selga, üks pole mahtunud, see ütelnud: "Kui mul enam ruumi ei ole, siis ma istun näki nägara peale!" Kohe kadunud hobune jõkke. (E 36825/6 (15) < Kadrina khk, Hõbeda k A. Kivi (1898).)

Rahvajuttudes eelneb näki nägemine sageli kellegi uppumisele. Võidakse kuulda häält: Päev jõuab, aga mees ei jõua! (Kadrina), mille järel mees upubki. 


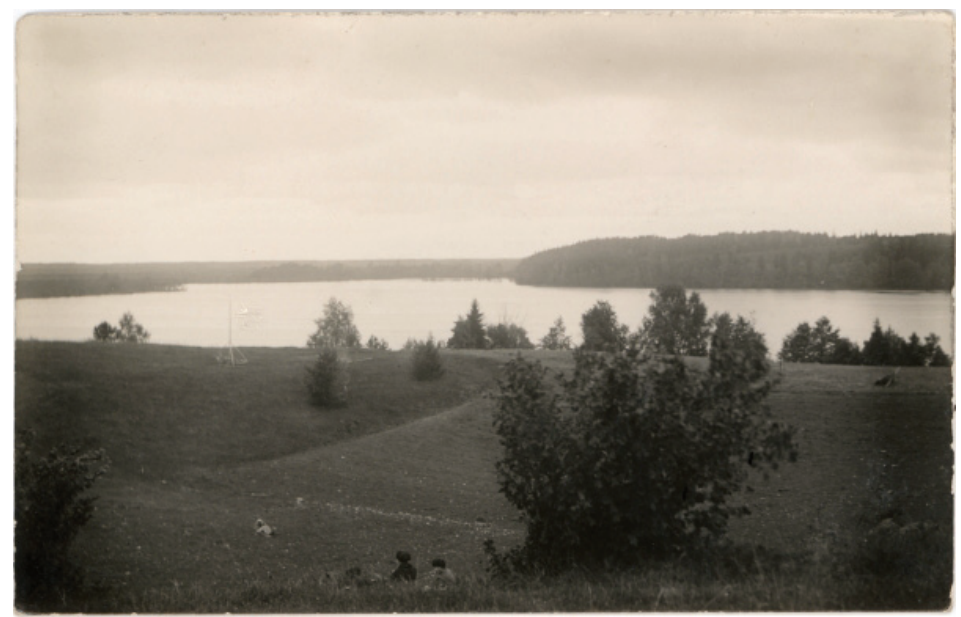

Foto 1. Uljaste järv - veehaldja asupaik. Viru-Nigula khk, 1930. aastad. ERA, Foto 1807.

Näkk võib ilmuda näiliselt kahjutu looma või linnuna: väike must loom (Simuna, Venevere k), vinguv punase karvaga koer (Jõhvi, Mäetaguse v), lambatall (Kadrina, Hõbeda k), ilma peata part (Viru-Jaagupi, Küti v).

Peipsi põhjaranniku vene kalurite keelepruugis on vetevaim vodjanoi, ka podledni ded (jääalune taat) ning eesti keelest üle võetud nimetus veehaldjas. Näki vasteks on russalka, kelle demoniseerumisaste on kõrgem - võrreldes eestlaste näkikujutelmaga on russalka märksa agressiivsem ja ohtlikum.

\section{Majauss}

Majauss on majahaldja kehastus (vt ka Hiiemäe 2006c: 338-339). Rahvapärimuses maja- ehk kodu-ussi kohta rõhutatakse tema tähelepandamatu olemasolu enesestmõistetavust. Mao nähtavaleilmumine eluhoonete juures on õnnetuste, hävingu, loomakahju, isegi pereliikme surma ettekuulutaja: Kui näitab ennast, siis on kohe paha, mis tahes kahi (Väike-Maarja, 1931). Inimesele majauss ohtlik ei ole.

Vana metsauss pidi ka igas majas olema. Temal on õigus näitada. Me külas ka üks maja põles, ahju alt tuli uss välja. Temal ei ole õigus puutuda. Metsas on tal voli, majas ei tohi hammustada. (ERA II 28, 322/3 (34) < Lüganuse khk, Püssi v - R. Põldmäe (1930).) 
Kujutelm majaussist kui õnneandjast on Euroopa rahvastel üsna ühetaoline. Tõenäoliselt peeti maoks, kes "ei tohi hammustada", nastikut. Majausse võib olla vägagi erinevat värvi (nt iga karilooma kohta üks). Muid erijooni välimuses pole. Majausse toideti sooja piimaga, eesti traditsioonis kuulub selle juurde kutsung "Piilu! Piilu!" Kimbutamise puhul, olgu meelega või kogemata, võis majauss üleloomuliku olendina ka kätte maksta või õnnetuse põhjustada.

Õhtu pandud kausiga piima põrandale pimetasse nurka ja hü̈tud: "Piilu, piilu!"Siis tuld ahju alt teisa igate karva välja ja hakand piima lakkuma. Võeralle tehtud ase maha, ena, eks üks ole üöse tema külle ääre magama pugend. Tema ehmatand kangeste ja trampind teist jalaga iemalle. Ommiku tuld peremies luome süötmast ära ja kurt: "Sina, külamies, tegid vist meie piiludelle häda. Meie kirju härg on laudas surnud. Võtt tulepieru ja hakkand mihe aseme ümber vaatama. Eks üks kirju uss olegi aseme juures surnud old. (H II 9, 556 (14) < Haljala khk, Kavastu v - V. Klaas (1890).)

Eesti Rahvaluule Arhiivi kogude järgi ulatuvad uskumused majaussist 20. sajandi keskmeni, levikualaks Harjumaa, Järvamaa, Virumaast vaid osa (Kadrina, Haljala, Rakvere, Viru-Nigula, Lüganuse, Viru-Jaagupi khk), Viljandimaa, Põhja-Tartumaa ning Setumaa. Säästva hoiakuga tõekspidamised on kõrvu uskumustega madudest kui piibellikust kurjuse sümbolist, kelle tapmatajätmine oleks patt.

\section{Laudavaim}

Kujutelm loomaõnne andjast, kes end nirgi näol näitab, on tuntud läänemeresoome ja Volga sugulasrahvaste, ka idaslaavlaste usundis. Soome, Eesti, Läti ja Leedu jäävad Ida ja Lääne kultuuri vahealale. Laudavaimuks peetakse hoonete juures nähtud nirki (niisama kärpi ehk suurnirki). Uskumused on kogu levikualal üsna sarnased (vt ka Ernits 2007).

Nagu majausski, kuulutab Virumaal arvatavalt iga maja juurde kuuluv endeloom ette karilooma või ka inimese surma, üldse halba: õnnetust, tüli, tulekahju, kolimist. Soomes ongi majakaitsjaks arvatud valget nirki, nimetuseks läävemato (laudamadu).

Loomakese vahelduva värviga karvkatte järgi (kevadel ja sügisel kirjulaiguline, suvel punakaspruun, talvel valge) otsustati, mis karva kariloomad paremini edenevad:

Nirk tõi nagu õnne. Arvati, et igal tallil on oma nirk. Keegi meie inimestest nägi, et siin on punase-valgekirju, siis pidid lehmad ka punase-valgekir- 
jud olema, siis on hea õnn. (RKM II 371, 550 (25) < Viru-Jaagupi khk, Inju k - M. Kõiva (1984).)

Nirgi laiba nägemine tähendas peatset karilooma hukkumist, mõistagi kehtis keeld nirki surmata. Mujal tuntud uskumust, et laudavaim vihkab ja kiusab karilooma, kes pole temaga ühte värvi, tuleb Virumaal üldiselt harva ette, ka on vaid nappe kirjapanekuid selle kohta, et ta käib hobuse lakka painajana palmitsemas. Küll aga kannab nirgina tegutsev vaimolend Peipsimaa vene rahvastikuga külades nimetust dvorovoi, dvornik (õuehaldjas), kipub piinama nii hobust kui inimest (Iisaku khk, Uusküla), või kui ühes majapidamises dvornik karja hooldab, siis teises nimelt kiusab ja vaevab (Iisaku khk, Imatu k; Vaivara khk, Omuti k).

\section{Maa-alused}

Kujutluse kõrval, et nn maast (või veest) saadud haigus - nõgeslööve vm nahanähud tekivad maa hingusest, eksisteerib rahvausundis ka teine, mille järgi haigusnähtude põhjustajaks on maa-alused vaimolendid. Nimetus maaljad võib niisiis olla lühenenud vorm nimetusest maahaldjad. Uskumus on iseloomulik soomeugrilisele maailmapildile.

Eesti usundis on kuulumine maa-aluste vaimolendite kategooriasse tunnuslik nimelt Virumaa ja veidi ka Järvamaa rahvapärimuses, ent rahvaluulekogumise algusaegadeks olid niisugused arusaamad juba tuhmunud. Kirjapanekutest Jakob Hurda ja Matthias Johann Eiseni rahvaluulekogudes selgub maaaluste etioloogia mitmetahulisus (Soomre 2000). Tegemist on inimesetaoliste pisiolenditega, kelle olemasolust annavad märku hääled. Öeldakse, et need on maa-alused inimesed, maavaimud, inimese moodi vaimud (Väike-Maarja, Iisaku); see on pisikene rahvas nagu härjapõlvlased (Viru-Jaagupi); maa-aluse sepad taovad tiks-tiks; teevad palju sepatööd (Kadrina, Väike-Maarja, Simuna, Viru-Jaagupi). Maa-aluste inimeste päritolu kohta lähevad ettekujutused lahku: sinna on surnud maetud (Viru-Jaagupi); äkilist surma surnud looma matusekoht (Simuna); kuri vaim kukkus taevast sinna kohta (Simuna, Vaivara). Üksmeelne on uskumus teispoolse ilma asukate haigestavast mõjust inimesele. Iseloomuliku hääle kuulmine on haiguse, hävingu, isegi surma ettekuulutajaks. M. J. Eiseni teatel ohverdati maa-alustele vaimudele must kukk (Rakvere khk).

Võrdlus sepatööga viitab Skandinaaviamaade ja ka Soome rahvausundis tuntud kujutlusele kääbusjast mäevaimust, millele omakorda rajaneb härjapõlvlase/päkapiku-kujutelm. Teisalt aga kuulub - taas nimelt Virumaal - sellesse üleloomulike olendite ringi veel ka toonesepa nimetust kandev mardikas. 
Maa-aluse sepad. Mis need peaksid olema?

- Seina sees on üks selts koisid (Motten od. Termiten), kes oma mängimisega korda löövad nagu sepad kunagi. Seal pidada maa-alused sepad raha taguma, ütleb vana eestlane. (H II 10, 561 (43) < Viru-Jaagupi khk, Rägavere - J. Uustallo (1889).)

Tooneseplaste (mööbli- ja suure toonesepa) tiksumist on Virumaal käsitatud kui surnuteilma märguannet elavaile, seosele toonelaga viitavad ka liiginimetused toonesepp, toonetikas (tikas tähendab rähni).

Maa-aluste nimetust kandvate haigusnähtude tõrje- ja ravimaagia püsis suulises käibes seostatuna vaimuilmaga, ulatudes 20. sajandi keskmeni. Nagu mujalgi Eestis, eriti veel maa läänepoolses osas, on ka Virumaal olnud esmaseks maagiavahendiks maa peale sülitamine enne maha istumist. Sageduselt järgmine on soovitus hõbevalget poetada paika, kust arvati haigus saadud olevat. Juhuslikumad tõrjemaagilised võtted on haige koha piiramine või vajutamine hõbe-esemega, vaskrahaga, mullaga, haigust toonud paigas pinnase tagurpidipööramine. Abi on otsitud ka mitmetelt iseloomuliku nimetusega taimedelt maaviharohtudelt, nagu mailase rohi, maavits jt.

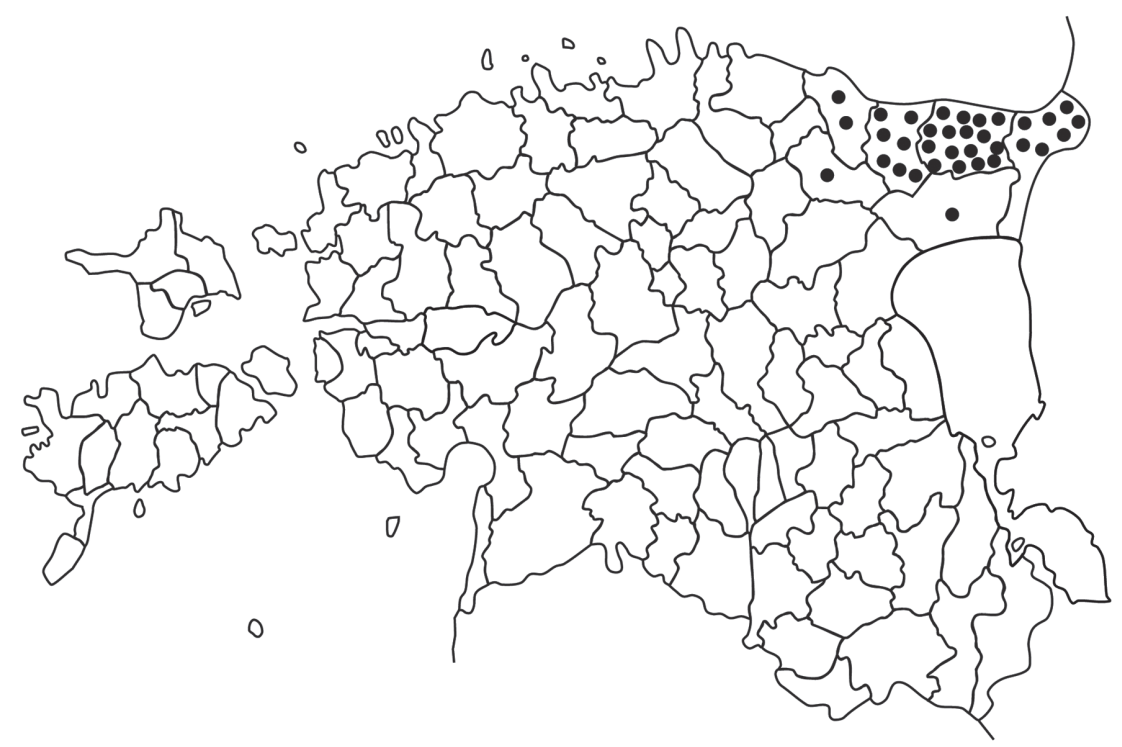

Joonis 1. Levikukaart. Uskumusteated toonesepa kohta. 


\section{Koerakoonlane}

Kujutlus koerakoonlastest (Lõuna-Eestis nimetatud peninukkideks) - pooleldi koeranäolistest, pooleldi inimesenäolistest metsikutest olenditest on arvatavalt ulatunud juba 13. sajandi ristirüütlite vallutusaega.

Koerakoonlased. Sõja-ajal toodud, enne, kui sakslased seia tulivad. Otsisivad metsades inimesed üles. Jõe ääres old puu otsas inimesed, varjud paistand vette. Koonukesed hakand vett lakkuma, tahtand kuivaks saada. Läksid lohki. Need olid koera moodi. (ERA II 28, 690 (22) < Viru-Nigula khk, Kunda-Malla v - R. Põldmäe (1930).)

Meie rahvaluulekogudes kirjeldatud koerakoonlaste koledat nägu ja agressiivset käitumist on kõige enam kujundanud viimatine 1877.-1878. aasta Vene-Türgi sõda, millest Vene tsaariarmee koosseisus võttis osa tuhandeid eesti mehi. Traditsiooni suulisele levikule sõjasttulnute vahendusel aitas kaasa võõraviha õhutamine ja propaganda ajalehtedes ning raamatutes. Virumaa pärimuses kulgeb ala, kus koerakoonlasi seostatakse türklastega (nn suur turk), piki põhjarannikut.

Suur turk on karvane, maa sees ketiga kõvast kinni. Lapsi hirmutati. Kett läheb katki, siis keegi ei jõua kinni hoida. (ERA II 28, 382 (14) < Lüganuse khk, Maidla v - R. Põldmäe (1930).)

Juba Fr. R. Kreutzwald märgib, et koerakoonlasi usutakse sõdade aegu viidavat peitupugenuid üles otsima. M. J. Eisen on koerakoonlasi pidanud lihtsalt sõjaröövliteks, hiljem aga vaimude ja tavaliste inimeste vahepeal seisvateks müütilisteks olenditeks (vt Hiiemäe 2006a: 113-116). Tegelikult koondab rahvapärimus väga erinevaid motiive maailma folkloorist. See on segu üliohtlikust loomaliigist, marodöörist, kükloobist, kel otsaees üksainus silm, samas ka veel omaette rahvatõust, kelle asukohaks on nimetatud konkreetseid või irreaalseid maailma paiku.

Konulased peavad ühel maal elama kõhe mittu tuhat ühes perekonnas mä̈̈ all, peavad sealt välja kippuma. Inimesed peavad vasta tõrjuma ja palki määst alla neile vasta lasma. Palgid peavad jälle jõge mööda tagasi tulema, et neist ilmaski puudu ei tule. Siis, kui nemad sealt välla tulevad, siis peab tulema maailma ôts. (H II 11, 127/8 (1) < Rakvere khk, Kohala k - V. Pender (1889).) 


\section{Mardus}

Mardus (paralleelnimetus marras, mardajus) on Eestis tuntud peaasjalikult meritsi Soomega suhtlevates piirkondades Virumaal ning Kuusalu ja Jõelähtme kihelkonnas. Mujalt on saadud eitavaid teateid või ebamääraseid oletusi. Tegemist on tuhmunud kujutelmaga surmahaldjast. Selle tundmist muistses soome rahvausundis kajastab nimetus marraskuu looduse sügisese hääbumise aja kohta (üldkeeles november, vrd eesti hingekuu, kooljakuu). Eesti poolelt tuleb silmas pidada sõna mardikas (ka: mardlane) usundilist tausta, sest mardikaid on peetud hingeloomadeks.

Rahvapärimusest võib leida marduse kohta kolmepidise seletuse. See on vaim, kes surma ette kuulutab:

Räägitakse, et vahel, kui öösel inimesed magavad ja pime tuba on, siis peavad kuulma, et nende toas vokiga ketretasse. Seda öölda: "Marras ketrab." See peab sinna talu rahvale surma tähendama. (H II 8, 129 (70) < Jõhvi khk - P. Paurmann (1889-1891).)

Nii Virumaa kui ka Põhja-Tartumaa pärimuses tuleb ette ka ööema nimetust: ööema ketrab.

Teisel juhul on tähelepanukeskmes kana või kukk ja nn neljasilmaga koer (silmade kohal teist karva laigukesed), kelle käitumine reedab kaude marduse lähedaloleku.

Kui kanad kurisevad, siis näevad mardust. Neljasilmaga koer haugub ja uriseb ööse, siis näeb mardust. (ERA II 28, 642 (5) < Viru-Nigula khk, Kunda-Malla v - R. Põldmäe (1930).)

Kolmandaks on mardust üsna sageli seletatud nimelt kodukäijaks (Virumaal paiguti veel: koopjalg). Täpsemalt on vahet tehtud ühes Haljala kihelkonnast laekunud pärimusteates: See, mis enne surma käib, on hea vaim ehk mardus. Aga see, mis pärast surma käib, on paha vaim ehk kodukäija. Seega on mardus siin vaid etteteataja, ei enamat.

\section{Katk}

Katk, nimetatud ka mustaks surmaks, on rahvausundis mütoloogiline haigusvaim, kelle olemuse lähteks said inimkonda laastavad katkuepideemiad, mis esimese aastatuhande keskmes jõudsid ka Euroopasse. Eestitki tabas õige mitu katkulainet, viimane neist Põhjasõja ajal, 1710. aastal. "Eesti Ma-rahva Kalendris” (1832) kirjutas Kadrina kirikuõpetaja A. Fr. J. Knüpffer surnud kariloomade 
ja inimliha söömisest nälja- ja katkuajal. Suuline pärimus seostab katku peamiselt Põhjasõjaga, külade tühjaksjäämisele järgnes uue asustuse kujunemine.

Vanad inimesed rääkisid, et pääle Rootsi sõda ja katku siin vallas veel ainult kolm peret järele jäänud: Kruusamäe Laekannul-vana talu pihlakate juures; Vahemetsa Kaevusaare ja Alekõre vahel - kaks pihlakat mäe otsas näitavad veel praegu, kus vanasti see talu oli, praegu on talu mäe all Tammsaare talu Vadi külas. (EKLA, f 199, m 35, $173<$ Torma khk, Laekannu k - A. Vihman (1928).)

Katkust pääsenutest said ka Paasvere rahva esivanemad, vaid kolm inimest jäi suulise pärimuse järgi alles Simuna kihelkonna Mõisamaa, Lasinurme ja Emumäe külast. Ka Avinurme kanti jäänud ainult kaks talu - üks Piilsi ja teine Kaevusaare külasse. Virumaa põhjapoolsetest küladest on asustusajalooliste muistenditega esindatud veel Lüganuse kihelkonna mereäärne Liimala küla ja teistest küladest lausa eraldi paiknev Tarumaa. Kõige idapoolsem katkust pääsenute elupaik on Toila: siin jäi alles kaks tütarlast, teine neist pages Rootsi, leidis sealt Elijase nimelise mehe ning tagasi Toilasse tulnud, asuti koos ühte kaldakoopasse elama.

Eesti värvikal katkupärimusel on enam ühist läänepoolsete rahvaste pärimusega, Alutaguse jääb selle leviku piirialale ja Jõhvi, Vaivara ning Iisaku kihelkonnas on katkujututraditsioon tagasihoidlikum kui mujal Põhja-Eestis.

Katkuvaim ilmub kõige sagedamini hallis või mustas rõivas mehe või poisina, harvemini naisterahvana, loomariigist on esindatud ennekõike (kodu)kits või koer, esemete seas on esikohal lõngakera. Inimese kujul ilmuva katkuvaimu abivahendiks on kepp või oda.

Foto 2. Simuna katkusammas - katku pidamajäämise koht. Foto Helmut Joonuks 1966. ERA, Foto 9358.

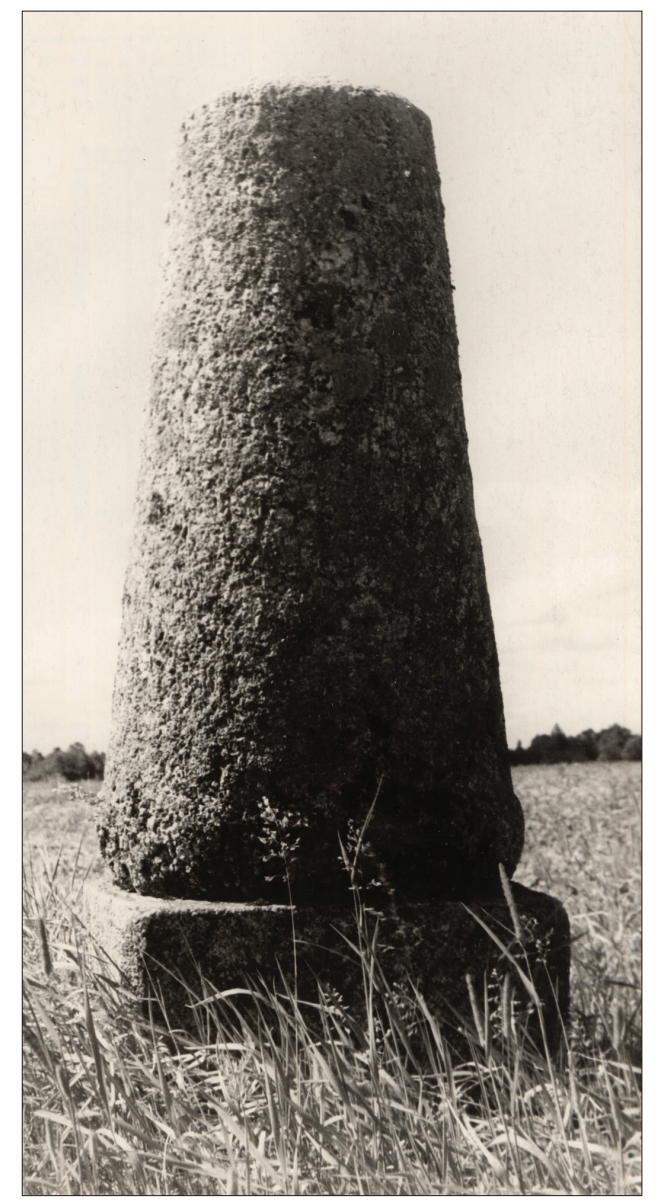


Kui siin maal on katk õld, siis on pilvese õhtatel katk joost pallajalu ja pallapäi, pikad juuksed ja pikk sau nagu toovrepuu, niske pikk old käes. Kui loomi või inimesi puutus kepiga, siis see kukkus ja suri. (ERA II 28, 293 (38) < Lüganuse khk, Püssi v, Kestla-Oidu k - R. Põldmäe (1930).)

Analoogset surmamisviisi on kirjeldatud Haljala, Lüganuse, Viru-Jaagupi, Simuna kihelkonna ja Narva tekstides. Katkuseemne või kihvti külvamisega tõbe levitavatest mõisasakstest jt pahatahtlikest inimestest on juttu Kadrina, Rakvere, Viru-Nigula, Viru-Jaagupi ja Jõhvi kihelkonna katkumuistendites.

Suur osa katkujuttudest keskendub ellujäämise põhjustele (vt Hiiemäe, R. 1997: 255-275). Katkusurmast pääseb isik, kes katkuvaimu sõidutab (Kadrina, Viru-Jaagupi), kes katku hüüdele ei vasta (Haljala, Viru-Nigula, Simuna), jätab üles võtmata kahtlase eseme (Kadrina). Pannakse tähele, et katk ei pääse üle vee, nt üle Paluoja, et Pada külla pääseda, või üle Pühajõe (Viru-Nigula, Lüganuse, Jõhvi). Lüganuse muistendis ei pääsenud katk Purtse Ristmäele ega Kestla külasse, kui see koht musta härjaga kündes vagudega piirati. Põhjarannikult on kirja pandud Soome rahvapärimusest levinud süžee, milles külahaldjas musta kukena katkupoisi küllailmumist takistab. Nii pääseb katku hävitustööst Haldja (Altja) küla. Käsmu lahe parempoolsel kaldal jäi Lobi küla mustast surmast puutumata sellepärast, et katkupoiss Unikivile uinus.

Veel 20. sajandi lõpukümnenditel on katkupärimust aidanud rahvasuus püsida toponüümid, nt Kadrina kihelkonnas Metsakülas Katku talu ja Katku mäed kalmega, Rakvere kihelkonnas Sõmeru vallas Katku (ka: Katkutaguse) küla. Paikadest, kus katku vanker katki olevat läinud ning haiguse kulg pidama jäänud, on kõige tuntum Simuna kihelkonna Katkuküla (Avanduse k) tänu 1849. aastal siia paigutatud geodeetilisele märgile (tähistab Struve meridiaankaare idapoolset otspunkti).

Simunast tulla, välja peal on kivipost. Seda räägitas, et vanast olnd nii suur katk, et rahvast surnd. Sinna posti juure jäänd katk peatuma. (RKM II 330, 410 (2) < Simuna khk, Paasvere v, Salutaguse k - E. Tampere (1978).)

Peipsiäärsete vene külade tšumaa (katk) on vastavuses idaslaavi katkukujutelmaga, katkuhaigus on ennekõike jumala karistus.

\section{Halltõbi}

Halltõbi on rahvausundis mütoloogiline haigus. Kuna halltõve (malaaria) peamiseks sümptomiks on hootine vappekülm, nimetatakse seda Virumaal 
rahvapäraselt külmtõveks, väristuseks ja äkiliseks haiguseks. Kroonilise malaariahaige nahk muutub hallikaskollaseks. Nimetus ork on Virumaal võõras, välja arvatud Avinurme (varem Põhja-Tartumaa koosseisus) ja Narva mail.

Halli ehk halltõbe on kujutatud inimesetaolisena nagu enamasti katkugi, tema ilmumine toob kaasa haigestumise (vrd Paal 1999). Veel 20. sajandi esimese poole kirjeldustes on suhteliselt palju isiklikke mälestusi: tuleb eemalt nagu must vari, hüüab oma ohvrit nimepidi (Simuna khk), raputab ninda, et lõdisen ninda nagu aavaleht (Jõhvi khk). Halltõve ringiliikumise eelisaegadeks peeti suuri sõdu (Krimmi sõda, Esimene maailmasõda). Haigestumist on seosesse viidud ehmatamisega (Simuna khk), külmetamise ja tuuletõmbusega (ViruNigula khk), aga ka teise inimese viha, kurjuse ja kadedusega (Viru-Nigula ja Simuna khk, Narva l).

Külmtõbi on kurjast. Enne oli igal kevadel külmatõbi liikvel. Narova lähikonnas nimetati teda “orka”. Kui nähti, et orka kirju kepi naal kuhugile peresse läks, siis jäid seal inimesed kõik külma tõbesse. Abi tuli targa juurest otsida. (E 27807 (12) < Narva - J. Sirdnak (1896).)

Haigusest hoidumiseks või sellest vabanemiseks kasutatud ennetava ning tõrjemaagia võtete arsenal on kirev, sageli on lähtutud mingist analoogiast. Peituda on soovitatud seapahna sisse, rukkisse, rukkipõllu ristvao vahele. Peipsiäärsest Tammispää külast pärit õpetuse järgi tuli end lakapeale rüsa sisse peita ja seal vagusi olla - haigusvaim asub kalapüügiriista võrgusilmi lugema ega saa oma ohvri kallale. Rahvusvahelise levikuga muistenditest on mõnedki Virumaal tuntud olnud. Simuna tekstis teeb hall enda prügiks ja pääseb nõnda tüdruku sisse, kui see piima joob, Viru-Nigula teisendis aga suudab inimene haigusvaimu üle kavaldada sellega, et lükkab lepapuul südame välja ning peidab õõnsa pulga oma kaenla alla, pärast aga keerab pulgale prundi peale ning riputab vangijäänud haigusvaimu haava otsa lõdisema. Kõige äärmuslikuma halltõve ülekavaldamise viisi on ühes pärimusjutus haigusega kimpus olnud tüdrukule õpetanud tark, soovitades tal end lehmakütkesse näiliselt üles puua. Hall tulnud laudauksele ja sõnanud: "Mari, Mari! Oh sina vana raibe, näe, poond enese üles. Ma paar päeva oleks veel käind, siis oleks su rahule jätnud.” (Viru-Nigula, 1921.)

Selleks, et kehasse tunginud haigust eemale tõrjuda, söödeti haigele sisse midagi eriti vastikut: siili liha või verd, koera verd, lutikaid, täisid, hobuse higi, (musta) lehma uriini, kärnkonna tuhka, kala kõhust leitud toorest kala. Haiget on soovitatud raisakontide veega vihelda, temast lambakari üle ajada, talle hobuserakmed ümber panna. Haigusest usuti lahti saavat ka, kui leivaahju luuda jalge vahel hoides mööda küla ratsutada. Taimsetest vahenditest on eelistatud väriheina teed, mis pidi värisemise ära võtma. 


\section{Vainuköis}

Vainuköie (Hiiemäe 2006c) moodustab tillukeste üksteise külge kleepunud, aeglaselt liikuvate ussikeste rida, mis meenutab köit. Tegemist on vaenusääse vm liigi vastsetega, kelle eriline olek ja kulgemisviis on paljude rahvaste usundis alust andnud kujutlusele millestki üleloomulikust. Selle kohta, et tegemist on siit ilmast lahkunute hingedega, keda vangist lahti päästa tuleb, pole Virumaalt 19. ja 20. sajandi rahvaluulekogumise aegadel ühtegi teksti kirja pandud, kuid vihjet sellele, et ussikeste koostlahutamine võiks heategu olla, võib mõnest tekstist siiski leida.

Vainuköied. Ma olen kahed näind ja lahti teind nimetse Matsiga ${ }^{3}$, sellega peab ea olema aiged vajutada, kui kael aige ehk paised. Niikui suur uss, eest jäme, takka peenike. Pisikesed ussid, mustad läikivad. Läksivad kõik takka ettepoole. Kukk ja kanad läksid mööda, aga ei puutund neisse. Enne öeldi, et on patt, kui lähed mööda ja neid ei lahuta, nad ei saa ühest ära. Kui vähe puudud, kohe lähvad lahku. (ERA II 38, 173 (9) < VäikeMaarja khk, Vao v - R. Põldmäe (1931).)

Mõnest kirjapanekust võib leida ettekujutuse, et igale inimesele vainuköit "ei näidata":

Sie köis, kellele seda näidäti, sellele näidätigi senepera, et lahutada tuleb. Taheti senele inimesele kõhe andada üks ia käsi. (Jõhvi khk, 1960.)

Teisal on mainitud, et kes neid näeb, peab lahutama. Kui lahutab, siis alati õnnelik käsi kõiges toimes (Haljala khk, 1926).

Teateid vainuköie väljanägemisest ja kulgemisviisist, ühtlasi meenutusi selle ebatavalise loodusnähtuse vaatlusest on Virumaalt laekunud tihedamaltki kui mujalt Eestist. Nende inimeste sünniaastad, kes ussikeste koostlahutamise tegelikult ette on võtnud, jäävad 20. sajandi algukümnendisse. Küllap oli usk käele imeväe saamisest sellal veel tõsiseltvõetavam. Enam on siiski kirjeldusi vainuköiest ja selle koostlahutamise eelistest mööndusega, et mina teda ei puutunud.

Ohutunnet vainuköis ega tema lahutamine endas ei kätke. Esile on tõstetud rahvaarste, kes heaks ravijaks saamise võlgnevad vainuköie lahutamisele. Nimetatud on mitut liiki haigusi ja sümptomeid: kõhuvalu, hambavalu, reuma, liigesehaigused, kurgupõletik (kahepoolsed), puhutised (hobusel tiirud), roos, paised, vistrikud. Raviviisiks on tervendava käega masseerimine, vajutamine, piiramine.

Seda, et vainuköie lahutaja targaks või rikkaks saab, et tal kõik tööd hästi edenevad, tuleb Virumaa pärimuses ette vaid üksikjuhtudel. Ainult Vaivara 
teates on vainuköit võrreldud sõdalastega. Teistel maailma rahvastel on kujutlus sõjaväest valdav ning kajastub nimetuseski (vrd saksa k Heerwurm, inglise army-worm, ladina militaris; kuulutab sõda, nälja-aega, liikumissuund näitab hävingut, surma). Soome uskumustes näitab littamato peidetud varanduse asukohta. Suurte euroopa keelte eeskujul on meiegi üldkeeles kasutusse jäänud nimetus vaenuköis. Varasem nimekuju viitab hingekujutelmale (vrd soome k vainaja - surnu). Pärimusteadetes märgib vainu mõnikord ka maastikutüüpi nurme või karjamaa tähenduses.

\section{Kodukäija}

Kodukäija on surnuvaim, kes hauas rahu ei saa ning hakkab oma endises kodus käima, ilmudes enamasti öösi. Eesti eri piirkondades on tal mitmeid nimetusi, Virumaal veel kaapjalg koapjalg, mardus marras, tont, kummitus, ka lihtsalt vaim. Hirm rahutu surnu ees on soodustanud matusekommete püsimist suhteliselt konservatiivsetena. Lahkunutel on elavatele omad nõudmised.

Üks rikas vanamees surnd, aga poig põle tehend õiete mattusi. Mattuselised rääkisivad, et vanamees akkab vist sene iest kodo käimä. Eks akanedki luamad lõppema. Kanad langened kõhe pennilt alle, õld surrud. (ERA II 166, 183 (58) < Jõhvi khk, Illuka v, Oru-Võhma k - A. Hallik (1937).)

Surnut arvati koju ilmuvat põhjusel, et talle pole soovitud rätti pähe pandud (Viru-Jaagupi, Iisaku), prille ette pandud (Rakvere), peiede pidamiseks looma tapetud (Vaivara, Iisaku); keegi võtab temale kuuluva asja (Simuna, Avinurme). Mõnedki kummitajad on olnud nimepidi laialt teada aastakümneid pärast surma: need, kes surid õnnetut surma, kes olid olnud kurjad ja pahatahtlikud, nõiaseltsi, kel rikkus koormaks, kel tööd pooleli jne.

Kodokäijaid õli küll. Minu vanemate vanemad rääkisid mitu kõrd, et mattuse ajal, kui saivad surne Iisakus maetud, õli tämä jua enne kodo kui mattuselised ja küsis, et kuhu te ninda kauast jäita. (ERA II 166, 336 (15) < Iisaku khk ja v < Jõhvi khk, Illuka v - A. Hallik (1937).)

Mälestusjutte enne matuselisi koju tulnud surnust leidub kõigist Virumaa nurkadest. Küllap aitas hirm teispoolsuse ees ebareaalset tegelikkuseks kujutada. Kadunukest võidi näha samuti loomana - koera, kassi, siku, lehma, härja, sälu, jänese kujul ringi liikumas. Kalmistul võidi kohata valges surilinas vaime, nimetatud on ka rõivadetaile.

Minu tädi rääkis, et tema tuld teise tüdrukuga, soand surnuaja väravasse, siin Maarja surnuaed, tuld kohe naesterahvas välja surnuaast kuuvalgel, 
valged sukad jalas, paljad sukad. Öeld talle: “Tere.” Ta öeld: "Hmh!” Nad old nii ehmatand, ei ole tohtind enam tagasi vaadata. Tuli see kodukäija Maarja poole, nad tuld Ärina poole. Sukad old jalas ja tanu peas. (ERA II 38, 261 (60) < Väike-Maarja khk, Vao v - R. Põldmäe (1931).)

Kuuvalgel ööl teed käies kohatud kodukäijast, kes maadlema kipub, on enam lugusid Lääne-Virumaalt (Haljala, Väike-Maarja, Simuna, Viru-Jaagupi). Siis tuli hoida selg kuu poole, et ta kuuvalgusest jõudu ei saaks. Iseäralik on ka teispoolsusest tulijate keelekasutus.

Kaks kodukäijat läksid Kadrina poolt Lasila poole ja vaidlesid. Jõudsid Valma külasse. Üks ütles: "Tats vana Valma." Valmalt jõudsid Pundi perre. Esimene jatkas: "Eta peras Punti, padjom Lasila paiku, musta mauku suimit!” (ERA II 32, 111 (3) < Kadrina khk, Saksi v, Saue k O. Paalberg (1930).)

Rahvusvahelise levikuga muistendid agressiivsetest, elavaid endaga kaasa viia püüdvatest kannibalistlikest kodukäijatest on Virumaa rahvatraditsioonis isegi vähem aktuaalsed kui mujal Eestis. Küll aga piinavad nad laudas loomi, avavad uksi, süütavad ja kustutavad tulesid, kolistavad pööningul, loobivad ja lõhuvad asju.

Me külas siin taga otsas pidi käima kodu. Pidi kisendama väravasamba otsas (kaks posti oli ja eri puu oli peal, seal peal kisendand). Puurisud ja kõik, mis lakast pidi lendama, virutas maha. (ERA II 28, $143(2)<$ Lüganuse khk, Püssi v - R. Põldmäe (1930).)

Kolistamise ja esemete paigastliigutamisega sai suhteliselt hiljuti tuntuks kolistajavaim (saksa k Poltergeist) ning andis kõneainet Kunda kummitusena. Eriti värvikana püsivad mõisasakste kohta räägitavad jutud. Isikuid teatakse nimepidi, neid nähakse oma valdustesse saabumas, rahutuna tubades liikumas ning toimetamas jne.

Siin Muuga mõisas üks endine tüdruk näind ka kunagi vaime. Tema olnud oma toas ja kuulnud köögist kolistamist. Läind vaatama. Vaadand ukse vahelt. Vanad mõisapreilid (kes tõeliselt olnud surnud ja maha maetud), olnud sääl mitmekesi koos ja kloppind koogitainast. Tüdrukule nad ütelnud: “Maie, ära sina nü̈̈d vahi, nüüd põle sinu aeg." (ERA II 13, 389/90 (15) < Simuna khk, Muuga mõis - R. Viidebaum (1929).)

Ennetavat, kaitse- ja tõrjemaagiat leidub matusekombestikus tänini: lahkunu viiakse majast, jalad ees, kadunu meelepärane ese pannakse talle kaasa. Varasema tavandi maagiavõttestik on olnud jõulisem, eriti kui oli põhjust arvata, et hüvastijätt pole lõplik (vt Viluoja 1978). Lahkunu jalad, ka sark on soovitatud 


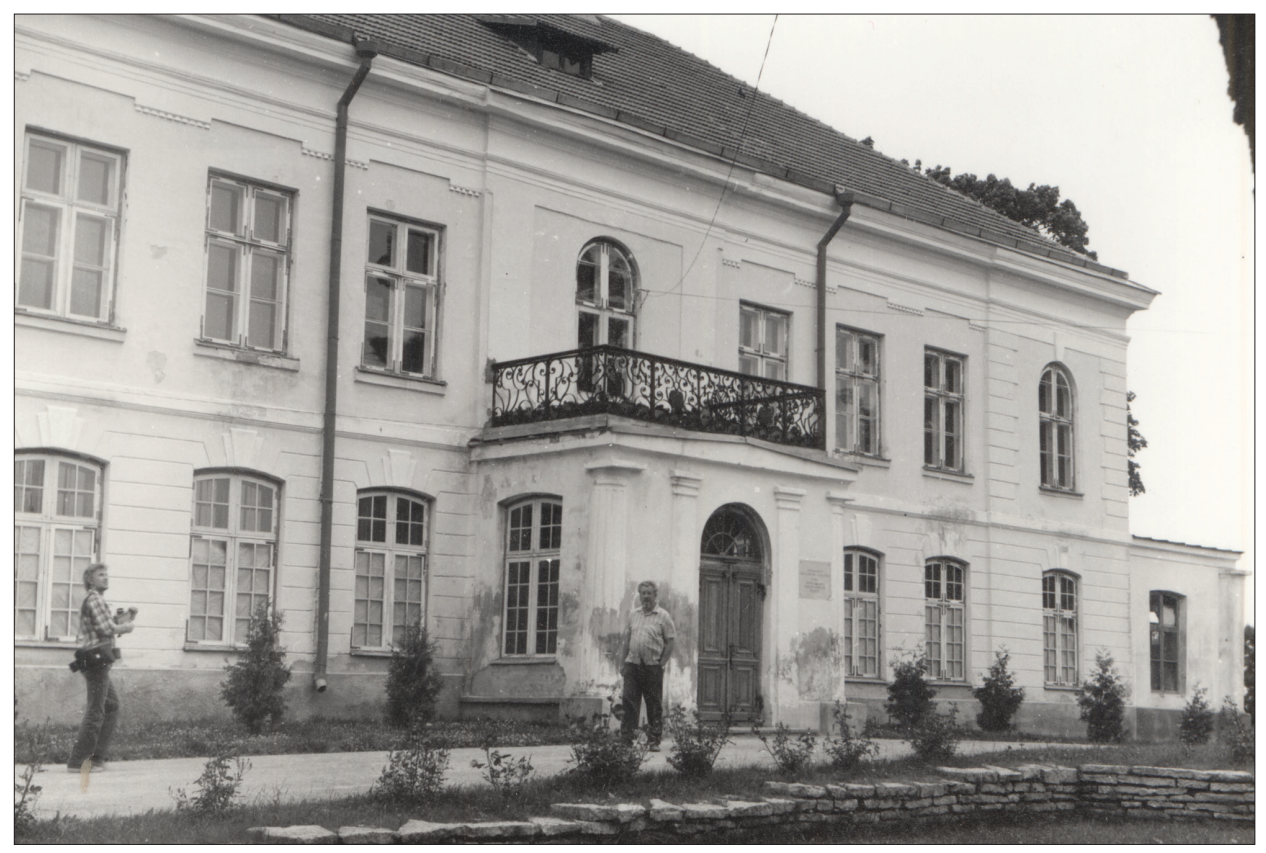

Foto 3. Rägavere loss - kummituskoht, kus öösi on hääli kuulda: mõisapreili hing ei saa rahu, ilmub koju. Foto Mall Hiiemäe 1984. ERA, Foto 13886.

kinni siduda punase lõnga või pihlakaväädiga, nimetatud on veel leppa (Rakvere), toomingat (Jõhvi), sõnajalgu (Väike-Maarja). Ümber maja on puistatud linaseemneid: kodukäija hakkab neid lugema ega jõua enne kukelaulu koju (Lääne-Viru). Puistata soovitati ka tuhka või soola (Simuna, Lüganuse).

Elas kõrd üks paha inimene, kes enne surma üteld: "Kui minu surnuaiale veeta, külvaga soola sinne ja ise ütelga, et ära enne tule, kui sool õrasele lähäb, kui seda ei ütle, siis tulen kodu käima.” Nii üteldi siis pea alati, kui keegi jälle suri ja teda maeti. (ERA II 215, 603/4 (17) < Lüganuse khk, Erra v - A. Jõesaar (1939).)

Eksitamiseks on sark majast välja viidud värava kõrvalt, üle risttee, läbi põõsaste. Kodukäijaga kohtumisel loodeti abi meieisapalve lugemisest, kalmu pühitsemisest. Kui mõisahärra kodukäijana toapoissi endaga hauda kaasa kutsub, ütleb see, et mingu härra ikka ees ja surub augu haual jalakannaga kinni. Uskumus, et vaimud kardavad hunte, oli tuntud samuti Alutaguse lõunaosa eestistuva elanikkonnaga külades (Liivaküla, Jõuga). Tuli öelda: Hundale! Hundale! et ilmuksid hundid ja kodukäijast jääks järgi vaid sinist suitsu. 


\section{Luupainaja}

Luupainaja näol on tegemist irdhingega, kes ilmub magavat inimest või karilooma (hobust, lehma) öösel vaevama. Kujutlust kehast lahkuvast hingeloomast leidub seoses painajaga enam Eestimaa läänepoolsetes piirkondades, Virumaalt kogutud pärimuses oli see 20. sajandi algusaastateks juba unustusse jäänud. Seevastu on rõhku pandud luupainaja (inimesel) ja painaja (loomal) kogemuslikule kirjeldamisele ning abinõudele tema vastu.

Kuna painajakujutelm lähtub teatavasti organismi seisundist tulenevatest füüsilistest vaevustest, ongi püütud neid seletada painaja olemasoluga:

Mõned inimesed ümisevad, mõned üösel kohe häälega räägivad, siis ei saa inimene ennast liigutada, teda rõhutakse, siis on painaja pial. (RKM II 371, 666 (21) < Viru-Jaagupi khk, Saueaugu k - M. Kõiva (1984).)

Karilooma vaevamist reedab enamasti looma rohke higistamine:

Luomidel ja ovostel käis painijas pääl. Õhta päält päiväluoja luamad inisesivad ja jäiväd märjäst. (ERA II 166, 334 (8) < Jõhvi khk, Illuka v A. Hallik (1937).)

Painajaks käimise põhjusi on esile toodud kaks: vastamata armastus ja teise inimese viha (pahameel, kadedus). Mõlemad on Virumaalt pärit noteeringutes esileküündivad: rohkem kui veerand kogu Eesti sellesisulisest ainesest. Virumaa kirjeldustes käib painaja peaaegu eranditult inimese, mitte looma või eseme näol (nt Kadrina tekstis kass, Väike-Maarjas must lammas, kass vm väike loom või mingi põllutööriist). Naaberrahvastelgi tuntud luupainajamuistendis ilmub kaunis neiu noormehe painajaks oherdiaugust ning, kui auk kinni lüüakse, tuleb talle naiseks. See jututüüp on küll rohkem tuntud maa lääneosas, kuid ei puudu ka Virus, levik ulatub Vaivara maile.

Painaja tõrjumiseks looma peal käimast on soovitatud üsna lihtsat teguviisi:

Kui tegid talli siginenud iseäraliku asja katki, kas teiba või mõne muu asja, siis järgmisel päeval oli pealkäija jala- või käeluu katki. (E 82894 (26) < Simuna khk, Käru k - K. Freienthal (1933).)

Selliselt ülekandemaagia võtet kasutades saadi teada painamaskäija isik - enamasti keegi lähikonnast - ega tulnud ta ka enam painama. Üsna populaarne on olnud linaharja panek piidega ülespoole, loomale kaitseks selga (u kolmandik Eestist kogutud variantidest on Virumaalt). Väärib märkimist, et see on ainus tõrjeviis, mis painajat ei talitse: ta keerab linaharja teistpidi, piidega allapoole. Üldiselt on metalsel terariistal (puss, nuga, kirves, vikat, raudnael vm) tõrjemaagias oluline koht. Kinnitada tuleb ta seina külge, ukse peale või 
künnisele. Looma löömine piitsa või pihlakavitsaga pidi tabama hoopis painajat, kelle kehale jäid asitõendiks vorbid. Vähem tuntud võtete seas on tõrvaga ristide tegemine looma seljale, meesterahva pükste või naisterahva seelikuga löömine, kolmekirjalise vöö kaelasidumine, vana viha või õlenuustiga vastukarva pühkimine. Inimest painama tulnu puhul on kõige olulisemaks peetud suure varba liigutamist.

Kompleks: painijas. Loe issameie ja liiguta pahema jala suurt varvast, siis kohe läheb menema. Ja päival ütle sellele inimesele, et sa käid, sõima tema nägu täis, siis ei tule. (ERA II 37, 611 (5) < Jõhvi khk, Võrnu k R. Põldmäe (1931).)

Veel on soovitatud painaja nime nimetada, teda avalikult, "suu sisse" hurjutada, jumalasõna lugeda, lauluraamat ööseks pea alla panna, magamiskohta vahetada.

Põhja-Peipsimaa vene külades on kasutatud nii vene kui eesti nimetust: dvorovik, dvorovoi (õuehaldjas) on üksiti painjas, panjas. Painjaks nimetatu käib nii inimesi kui loomi rõhumas (Jõuga k), hobust piinab ta nirgina (Uusküla). Uskumustes on vene traditsioonile omast: üks dvorovik hoolitseb karja eest, teine piinab loomi (Imatu k, Omuti k). Tõrjeks tuleb vedrupeaga noale rist peale tõmmata ja see lauta viia, meieisapalvet lugeda, hommikul kolm ust korraga lahti hoida. Vasknarva pärimusteates on rõhutatud, et dvorovik ei näita end kunagi.

\section{Libahunt}

Eesti folklooris on libaloomade seas esikohal hunt, juttu on ka ilveseks muutumisest. Kujutlust demonistlikust libahundist aitas Eestis koduneda huntide suur arvukus, sagedased kallaletungid koduloomadele ja veel 19. sajandil ka inimestele. Läänepoolse kultuurihoovusega Eesti alale jõudnud muistendimotiivid libahundiks muundumisest on üle maa tuntud (vt Metsvahi 1999).

Inimene sai ennast undist ka teha. Pani undi naha selga ja käis ümber kivi. Tema tegi kahju ka, kui sai. (ERA II 125, 163 < Jõhvi khk ja v, Tarakuse $\mathrm{k}<$ Iisaku khk - M. Tarum (1936).)

Kui hundikskäijatele on omistatud kariloomade murdmist ja verejanu, siis hundikspandutest jutustamisel neid omadusi ei rõhutata. Lood hundiks muudetud inimestest - soenditest on venemõjulisena iseloomulikud Eesti ida-alal (vene k oboroten). Omatahtsi hundiks käija on ise nõiaoskustega või kasutab nõia abi, ent soend on nõia poolt selliseks muudetud ning võib taas inimeseks 
saada tänu maagilisele toimingule. Traditsioonilises muistendis on pulmarahva soendiksnõidumise põhjuseks asjaolu, et sandil ei lubata pulmamajas ööbida, peig ei võta naiseks nõia tütart vm.

Jälle tehtud ühes kohas pulmarahvas undist, kõigil allid undivattid seljas, jooksid metsa. Siis kuntsimees või ambamees teand, et kuda neile abi saab. Oli mend metsa see nõid ja oli andand ühele või kahele suure noa otsast leiba. Kui unt ahmas leiva suhu, siis kukkus undinahk ära ja inimene tõusis püsti, oli sama inimene kui ennegi. Akkas rääkima, et ea, et sa leiba andsid, me olime undid. (ERA II 37, 586/7 (23) < Jõhvi khk, Võrnu k < Kiikla k - R. Põldmäe (1931).)

Teise tüüpsüžee järgi käib libahunt oma last imetamas, visates seniks hundinaha seljast. Inimeseks saab ta siis, kui hundinahk salaja ära põletatakse.

Põhja-Eestist on veel 20. sajandi esimesel poolel talletatud pärimust loomaliigi kohta, keda on nimetatud libahundiks, Virumaal (Haljala, Viru-Nigula, Simuna, Iisaku teadetes) samuti libehundiks.

Libedad undid, need olid pisemad kui teised undid, aga kanged kiskuma. Isekarva ka olid, pruunid ja lühikese karvaga. Kui veel ullumeelsed olid, siis olid ästi kardetavad, kiskusid inimesi ja loomi. (ERA II 38, 360/1 (26) < Väike-Maarja khk, Porkuni v, Nurmetu k - R. Põldmäe (1931).)

Kirjeldustest selgub, et mütoloogilise libahundi tunnusjooni üle võtnud agressiivne, kariloomadele ohtlikuks peetud loom on ahm ehk kaljukass (tegelikult kärplane), Euraasia põhjaosa loodusmaastiku asukas, kelle levila on varem ulatunud Eestisse. Välimuse kirjeldustes (vrd Hiiemäe 2006b: 352-354) on rõhutatud punakaspruuni karvkatet, ludus kõrvu, teravat või libas koonu. Mõnedki on teda kohanud, tunnistatakse, et ta on hundist väiksem (Jõhvi, Viru-Jaagupi, Simuna, Väike-Maarja). Kõige enam on rõhutatud, et libahunt murdvat looma tagantpoolt, pugevat tagant sisse, kiskuvat sooled välja (sama uskumus on komi küttidel).

Libaunt - see on ka undi seltsi, terava nenaga nenda kui praegu on poletseikoerad, pika nenaga, nössi kõrvadega. Ta oli natukene veikene. Tema tõmmas tagant obose reietuuma ära, aga päris-unt üppas kõri. (ERA II 37, 639 (9) < Jõhvi khk, Kohtla v, Ereda mõis < Mäetaguse v, Atsalama k - R. Põldmäe (1931).) 


\section{Tuulispask}

Tuulispask kujutab endast mütologiseeritud ilmastikunähtust. Üleloomuliku olendi mõistes on tegemist irdhingekujutelmaga. Inimese kehast lahkub tema hing tiivulise putuka (kärbse, herilase vm) kujul, liigub tuulekeerise näol ringi ning siirdub seni liikumatult lamava inimese suu või nina kaudu ta kehasse jälle tagasi. Virumaal kasutatud nimetuste lähteks on peamiselt esinemiskuju: see on tuulekeerd, tuuleiil, tuulispä̈̈ (enam Lõuna-Eestis), vesipüks. Kirjeldustes on rõhutatud trombile omast: tõstab majad üles (Lüganuse, Viru-Nigula), viib kangad taeva alla (Avinurme), Püssi jaama juures laotas puupinu raudteed mööda laiali (Simuna), tõstis 7-aastase lapse õhku (Jõhvi).

Tuulispasa mütoloogilisest olemusest on Virumaalt, kus sellekohane pärimus juba 19. sajandi lõpuks unustusse jäi, vähem kirjapanekuid kui läänepoolsest Eestist. Nii on kujutluski veidi laialivalguv. Koondportree tuleb ilmsiks erinevate iseloomustuste kaudu: Ütlevad, et nõid sõidab, aga on tuulekeer lihtsalt (Simuna), see on kunts, vihavaenlane saatis (Lüganuse), keegi saadab, üks paha (Viru-Nigula), paha inimese vaim (Iisaku). Selguvad ka tema eesmärgid: Tuulispasa seljas sõidab vana Soome nõid ja korjab omale viljaseemet (Haljala), vanapagana toss tuleb (Simuna), Pidi tonditaolist olema. Vana kuri, võtab heinast ja viljast (Lüganuse). Võrdlust tondiga (see on Virumaal varavedaja - krati - eelisnimetus) tuleb ette mujalgi (nt Väike-Maarja, Simuna). Kuigi pahategijat on kuradiga seosesse viidud, ilmneb tõrjemaagiat vahendavast pärimusest, et see, kes Simuna pärimusteates korjab vilja kotti külvi ajal või Kadrina teates käis põllega rukkid võtmas tuulamise aegu, on nõiavõimetega inimene kusagilt lähikonnast.

Kõige sagedamini mainitud tõrjemaagiliseks võtteks on tuulekeerisesse terariista (noa, kirve, sirbi) heitmine (Viru-Nigula, Lüganuse, Iisaku). Mõju võib olla kahesugune: tuulispask kas pillab oma noosi maha ja kaob nähtamatuna, või (sagedamini) selgub, et pahategija sai terariistaga viskamisest rängalt vigastada või koguni surma. Vähem on kirjeldatud muid traditsioonilisi võtteid tuulekeerise sees olija nägemiseks või tema tegevuse takistamiseks: tuleb vaadata läbi auguga kivi või läbi jalgevahe, visata kivi või kaikaga, kanna tagant risti seotud pastlapaelad kiiresti katki lõigata, särk peaaugust sabani seljas lõhki käristada või loitsusõnu lausuda.

Mõne teate järgi (Viru-Nigula, Lüganuse, Jõhvi) on tuulispasa nägemine lihtsalt halb enne, mis kuulutab kahju, õnnetust või haigust ette. 


\section{Kratt}

Kratt on varavedaja, tehisolend, kellele hing sisse saadakse, kui tema valmistaja kuradiga lepingu sõlmib. Laenulist nimetust kratt (rootsi k skratt) tuntakse küll kogu Eestis, kuid rohkesti on muidki nimetusi: pisuhänd, tulihänd, varakandja, tont, puuk, vedaja. Virumaal on varavedaja eelisnimetuseks tont. Ühes Lüganuse tekstis on teda nimetatud lennuseks. Tont, kes lendab, tulejutt taga, oli Iisaku khk Imatu ja Jõuga k venekeelsete elanike keelepruugis zmejaa (madu). Alliku külas öeldi, et tont, kes piima toob, on strelaa (nool).

Tont ja tulihänd on siit rahva juttu järele üks ja see sama. Tulihänna ja varakandja nimi tulevad siin arva ette, aga ikka tont. Tont toob, tont viib jne, need on siit rahva ütelused. Kratt, puuk ja pisuhänd ei ole siin kuulda. Tont elab toa lakkas, käib kattuse olvist või nukast sisse ja välja. Tont on ise must, tuline saba taga, toob ja ka viib vara, jne. "Toa lakkas tonta palju." Lastele ööldakse: "Ära mine lakka, lakkas on tontid” jne. Haigusi tont ei too, on aga muidu üks kardetav elukas. (E 22497 (9-I) < Haljala khk, Metsiku - D. Pruhl (1895).)

Virumaa muistendites toob kratt oma peremehele peaasjalikult vilja. LõunaEestis on varavedajaks puuk, kes ilmub kassi kujul ja oksendab piima, Harjuja Läänemaa kratt oksendab aga silku. Õhus kulgeva varandusetooja kõige olulisemaks tunnuseks on helendav saba. Viru-Nigulast pärit kirjapanekus isiklikult nähtud krati kohta on öeldud, et kui kratil on madal lend ja saba madalal, siis on ta varandusekoorem raske. Kerkib küsimus, mida siis ikkagi tegelikult nähakse, sest vaatlusi pole vähe ja need on mõnigi kord üsna detailsed.

Kord sõitsime öösi Narva jõel paadiga, olime kolmekesi. Korraga näeme Narva poolt tulevat valget tulekera, sädemed aina lendavad, läheb meist mööda ja laskis maha ennast Omuti küla juurde männitukka. Ta lendas kui valge kajakas, aga aeglasemalt. Oli kera sarnane, umbes 12 tolli läbi mõota; sellele järgnes veel teine tulekera suuremana, aga tumedam, ja kolmas, mis kõige tumedam neist. Neljas kera oli pisike, aga väga hele. Taga oli lai saba, mis ka helendas. Siis kuulsime sellest männikust vareste kisa. Muide kartsid seda männikut kõik, sest sääl pidid vaimud ja tondid koos käima. (ERA II 125, 312/3 (2) < lisaku khk, Illuka v - M. Tarum (1936).)

Kõige enam on kirjapanekuid krati tegemisest ja tema pidamisega seotud probleemidest. Nimetatud on talusid, kus kratti peeti, ning isikuid, kes tema abil rikkaks on saanud. Ristteel ilmuvale kuradile tuli kolm tilka verd anda ning teada oli, et kratipidaja hinge pärib kurat. Varandusetooja valmistamiseks kasutatavate vahendite loendisse kuulusid talupere käepärased asjad. 


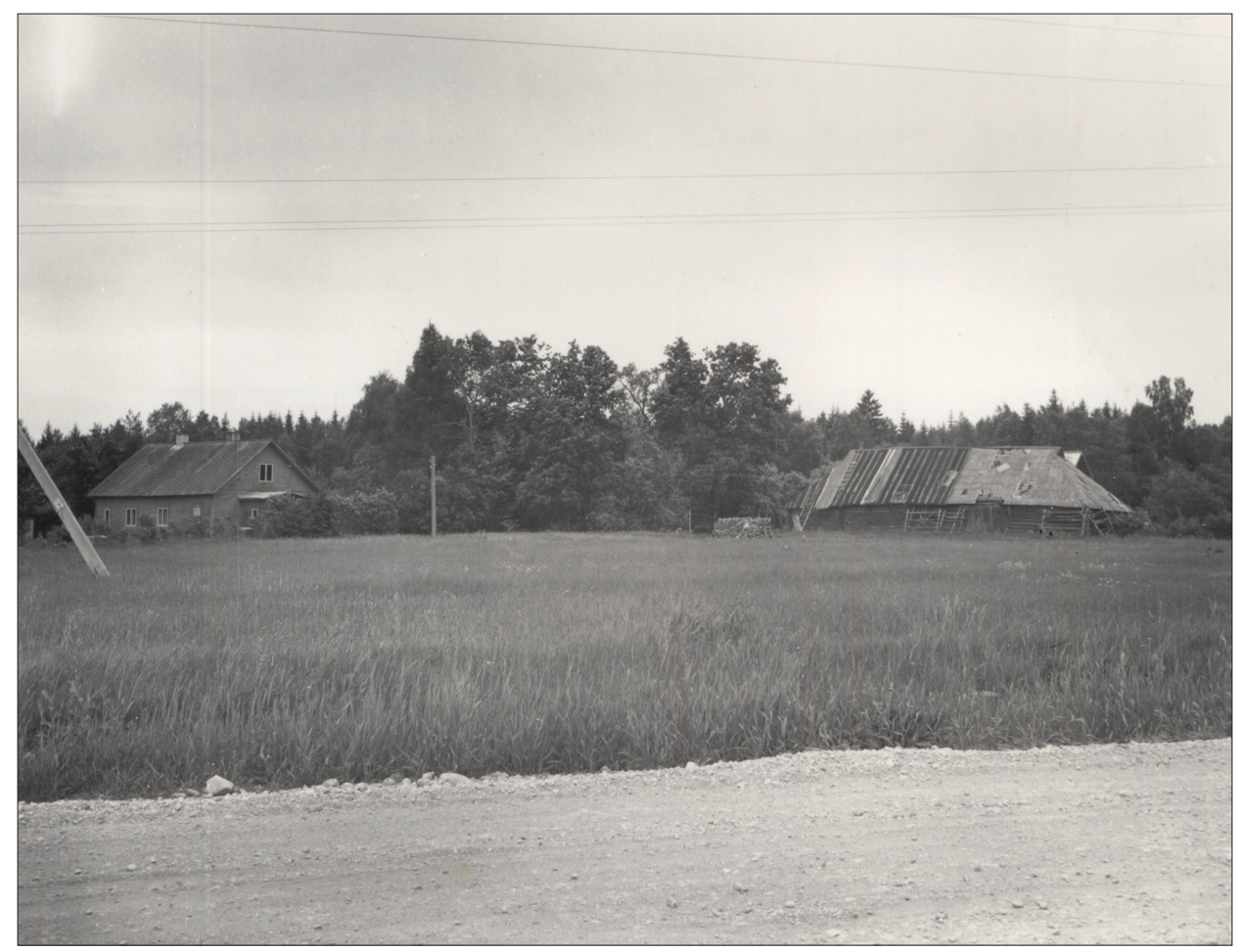

Foto 4. Rehetare Viru-Jaagupi khk Roostava k, mille ulviaugust tont sisse käis. Foto Mall Hiiemäe 1984. ERA, Foto 13887.

Tonti tehtud kolm neljapäeva õhtut ristteel. Materjaliks kulund kanganiisi, hernevarsi, köit, vanad puukausi poolikud (persekannikateks), vana viht (sabaks), voki lühiraud (lõualuuks) jne. Hinge sissesaamiseks pidand valmistatavale tondile varastama kirikust armulauaviina, suhu jätma ja koju tooma. Kui tont kraami pole saand tuua, siis tilkund tuld. (ERA II 12, 289 (1) < Simuna khk, Lasinurme k - R. Viidebaum (1928-1929).)

Selleks, et kratt või irdhinge kehastus tuulispask oma koorma maha pillaks, on esmatähtsaks peetud ristis pastlapaelte katkilõikamist. Simuna ja Haljala uskumusteadetes on mainitud ka nööpide lahtitegemist. Viljatuulamise ajal tuli kirves uksepiida sisse lüüa (Väike-Maarja, Viru-Jaagupi), aidas tehti viljasalvele rist peale või pandi kaitseks hobuseraud kumerusega väljapoole (Kadrina, Simuna, Avinurme). Aina tööd nõudvatest ja peremeest kägistama kippuvatest krattidest lahtisaamiseks soovitati, nagu rumala kuradi juttudes, neile üle jõu käivaid ülesandeid anda: liivast köit keerutada (Lüganuse), ilma põhjata kott täita (Kadrina, Simuna, Lüganuse, Jõhvi, Iisaku), sõelaga vett 
kanda (Jõhvi), talvel maasikaid tuua (Haljala, Jõhvi). Krattide toitmise kohta käib populaarne muistenditüüp.

Ühel mehel ôli kaks tonti. Nendel ôli alati valmis veedud putru. Ühekõrra sulane õli söönd putru ära ja sittund kaussi ja kust silmast. Tondid tulid sööma. Üks mekkind: “Äkkä-puppu!” Tõine öeld: "Illi-puppu!” Üks jälle:

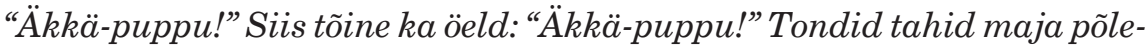
ma panna. Panidki. Aiateibas õld rattarumm, ise pugesid sinne sisse. Sulane jälle viskand sene ka tulde, et mis seegi järele jääb! Siis saivad tondid otsa. (ERA II 125, 380 (48) < Lüganuse khk, Maidla v - M. Tarum (1936).)

1970. aastatel levinud ufo-usk toob esile küll ufode ja tulihänna välimuslikke ühisjooni, ent mitte enamat. Eesti Rahvaluule Arhiivi välitööde käigus 1978. aastal Simuna ja Väike-Maarja ning 1984. aastal Viru-Jaagupi khk ilmnes, et uskumused kratist pole ufo-uskumustega põimunud, ent ka mitte päriselt unustusse jäänud.

\section{Lõpetuseks}

Usundilise maailmapildi taandudes on 20. sajandi vältel aktuaalsuse kaotanud mitmed muistendite temaatilised rühmad, vastavalt ka juttude eriilmeline tegelaskond, nt kaitsehaldjad, haigusvaimud, mütologiseerunud ja demoniseerunud sõjaröövlid, soendid jts. Kõige püsivamaks on osutunud kujutelmad surnuvaimust.

\section{Kommentaarid}

1 Artikkel on seotud uurimisprojektiga "Folkloor kultuurilise kommunikatsiooni protsessis: ideoloogiad ja kogukonnad" IUT 22-4.

${ }^{2}$ Vanakurja eufemism.

${ }^{3}$ Neljas sõrm pöidlast arvates.

\section{Arhiivilühendid}

\section{Eesti Kirjandusmuuseumis}

E - M. J. Eiseni rahvaluulekogu

ERA - Eesti Rahvaluule Arhiivi kogu

$\mathrm{H}$ - Jakob Hurda kogu 
RKM - Riikliku Kirjandusmuuseumi rahvaluulekogu

EKLA - Eesti Kultuuriloolise Arhiivi käsikirjade kogu

\section{Kirjandus}

Ernits, Enn 2007. Vadja koduhaldjate lemmikud ja vaenlased. Mäetagused 35. Hüperajakiri, lk 27-46 (doi: 10.7592/MT2007.35.ernits).

Hiiemäe, Mall 2006a. Kas koerakoonlased olid sõjaröövlid? Sõnajalg jaaniööl. Eesti mõttelugu 73. Tartu: Ilmamaa, lk 113-123.

Hiiemäe, Mall 2006b. Kas mälestused ahmi esinemisest Eestis? Sõnajalg jaaniööl. Eesti mõttelugu 73. Tartu: Ilmamaa, lk 352-359.

Hiiemäe, Mall 2006c. Must madu, maa-alune. Sõnajalg jaaniööl. Eesti mõttelugu 73. Tartu: Ilmamaa, lk 336-340.

Hiiemäe, Mall 2006d. Vainuköis rahvapärimuses ja looduses. Sõnajalg jaaniööl. Eesti mõttelugu 73. Tartu: Ilmamaa, lk 302-307.

Hiiemäe, Mall 2015. Virumaa vanad vaimujutud. Rakvere \& Tartu: Viru Instituut \& Eesti Kirjandusmuuseumi Teaduskirjastus.

Hiiemäe, Reet 1997. Eesti katkupärimus. Eesti muistendid. Mütoloogilised haigused I. Monumenta Estoniae Antiquae II. Tartu: EKI folkloristika osakond \& EKM Eesti Rahvaluule Arhiiv.

Metsvahi, Merili 1999. Muundumised libahundimuistendis. Hiiemäe, Mall \& Oras, Janika \& Tamm, Kadri (toim). Lohetapja. Pro Folkloristica VI. Tartu: Eesti Kirjandusmuuseum, lk 111-122 (www.folklore.ee/rl/pubte/ee/NT/profo6/Metsvahi.htm - 15. märts 2017).

Paal, Piret 1999. Malaaria rahvameditsiinis - haiguse tunnused ja haigestumise põhjused. Hiiemäe, Mall \& Oras, Janika \& Tamm, Kadri (toim). Lohetapja. Pro Folkloristica VI. Tartu: Eesti Kirjandusmuuseum, lk 123-132 (www.folklore.ee/rl/pubte/ee/NT/profo6/ Paal.htm - 15. märts 2017).

Soomre, Kristel 2000. Eesti maa-alustega seotud tekstide liigitamine. Hiiemäe, Mall \& Oras, Janika (toim). Maa-alused. Pro Folkloristica VII. Tartu: Eesti Kirjandusmuuseum, lk 105-112 (www.folklore.ee/rl/pubte/ee/NT/profo7/maaalused.pdf - 15. märts 2017).

Valk, Ülo 2008. Inimene ja teispoolsus eesti rahvausundis. Viires, Ants \& Vunder, Elle (koost, toim). Eesti rahvakultuur. Talllinn: Eesti Entsüklopeediakirjastus, lk 379-395.

Viluoja, Eha 1978. Sõnamaagia kodukäija tõrjes. Viks, Ülle \& Pall, Valdek (toim). Sõnast tekstini. Tallinn: ENSV Teaduste Akadeemia Keele ja Kirjanduse Instituut, lk 117-135.

Mall Hiiemäe - Eesti Kirjandusmuuseumi Eesti Rahvaluule Arhiivi vanemteadur. mall@folklore.ee 


\title{
Summary
}

\section{Imagery of supernatural beings in the folk belief of Virumaa}

\author{
Mall Hiiemäe
}

Keywords: cultural contacts, demonisation, form, free spirit, mythology, omen

The article discusses folk beliefs and narratives about supernatural beings in Virumaa, one of the regions in north-eastern Estonia. The region under discussion is situated in the area where cultural currents from the West and East intermingle, revealing common features with Germanic and Eastern Slavic traditions, with a noticeable Finno-Ugric substrate. Attitude towards forest fairies is rather neutral; according to the beliefs of indigenous forest belt peoples they often help humans. The water spirit is not always supposed to be hostile but is presented as the ruler of waters and protector of fishes. The beliefs held in the Russian villages in the area of Lake Peipus, on the other hand, feature the water spirit as a demonised, aggressive spirit. The latter is also true about the barn spirit, who tortures the cattle it does not like.

By the end of the 19th century mythological fantasies, for example, legends of especially hostile beings - the plague, nightmares, and dog-faced plunderers - in active narrative tradition faded away. Two aetiologies have been presented about the werewolf: a human being either turns into a wolf or is bewitched into one. Imagery of the dead spirit has been rather persistent and even today memorates about experiencing it are narrated.

Mall Hiiemäe is Senior Research Fellow at the Folklore Archives of the Estonian Literary Museum.

mall@folklore.ee 